\title{
Trust in Effective International Business Cooperation: Mediating Effect of Work Engagement
}

\author{
Małgorzata Chrupała-Pniak, Damian Grabowski, \\ Monika Sulimowska-Formowicz
}

\begin{abstract}
A B S T R A C T
Objective: This study aims to analyse the relationships between relational competence and its trust-building processes with individuals' traits considered as psychological antecedents of inter-organizational relationships (IORs), outcomes. We hypothesize that organizational trust-building competence, situational trust, trust propensity, and autonomous motivation of cooperating teams and their managers influence IORs outcomes through work engagement of cooperating people.
\end{abstract}

Research Design \& Methods: We addressed 210 managers and 982 employees responsible for inter-organizational cooperation from medium and big companies. As explanatory model we adopted the job resources-demands (JR-D) model. Correlation, regression, mediation analyses with bootstrapping, and structural equations modelling (SEM) were used.

Findings: Our analyses confirmed positive role of both organizational competences and psychological states of individuals, as valuable mediators in translating the potential of personal traits of teams and managers into IORs outcomes.

Implications \& Recommendations: As both psychological variables of people responsible for the course of IORs and relational competences of organizations play a vital role in reaching outcomes in IORs attention should be paid simultaneously to both aspects. Our findings highlight the necessity for interdisciplinary research in the field of IORs.

Contribution \& Value Added: We expose the multilevel and multifactor character of relationships between the antecedents of firms success in IORs, with the use of relationships theory in organization science, and theories proposed by psychology of work and organization.

\section{Article type: research paper}

Keywords: inter-organizational relationships; trust-building competence; inter-

JEL codes: organizational relations; job demands- resources model

\section{Suggested citation:}

Chrupała-Pniak, M., Grabowski, D., \& Sulimowska-Formowicz, M. (2017). Trust in Effective International Business Cooperation: Mediating Effect of Work Engagement. Entrepreneurial Business and Economics Review, 5(2), 27-50, DOI: http://dx.doi.org/10.15678/EBER.2017.050202 


\section{INTRODUCTION}

The international context of inter-firm cooperation with its additional features, such as geographical distance and cultural differences determining the scale of psychical distance between partners requires a special effort to ensure the relationship with favorable context. It is necessary to build a transparent, mutually acceptable framework for the relationship. This requires the ability to create an atmosphere of trust and credibility of partners, based on an optimal mix of contractual safeguards and relational mechanisms, as well as on a set of competences necessary to manage the relationship.

Effective participation in international IORs (inter-organizational relationships), requires the company to have specific core competences. Relational competence (RC) consists of abilities to choose a partner, plan the relationship, coordinate its course and execute effective control, as well as: communicate effectively and integrate partnering companies, solve arising problems and learn from one another. All those competences stem from organizational procedures, capabilities and resources and as systemic, dynamic relational competence are, at least to some extent, responsible for creating an organizational environment for effective IORs. It is also widely believed that among other conditions shaping the atmosphere of IOR and mutual behavior of partners, trust is a sine qua non condition for effective cooperation, so those components of RC that affect trust-building may also be of value.

Apart from organizational competences of building trust and managing IORs, it is also crucial to possess valuable HR (human resources) potential. Human resources in IOR are treated both as relational capital of collaborating members of the partnering companies, and as social capital of a company - its managers, teams and individuals affecting IORs' outcomes by their individual traits, attitudes and resources. Most of the research on IORs concentrate on especially valuable personal networks of employees and their social or interaction skills (Walter, 1999; Ritter, 1999; Speakman \& MacAvoy, 2000; Phan, Styles \& Patterson, 2005; Äyväri \& Jyrämä, 2007). There is a lack of analyses searching for relationships between organizational competences and personal characteristics of individuals. Psychological resources of teams and individuals responsible for execution of all collaborative processes might affect IORs outcomes, the use and development of relational competence and people's propensity to develop their social resources.

In order to fill the gap in IOR literature on joined research of organizational features and personal characteristics, potentially valuable for successful IOR, we aim at analyzing the relationships between relational competence and its components substantial for trust-building processes, with individuals' traits that we consider psychological antecedents of IORs outcomes. So far management science is lacking a universal theoretical model allowing to analyze both psychological traits of individuals and organizational variables as potential determinants of effective economic cooperation. In our opinion, a useful tool may be transferred from the organizational psychology to the ground of management science. We decided to use the job demands - resources (JD-R) and evidence-based work engagement models, because they highlight personal, organizational and contextual factors conducive to work engagement of individuals and thus determining their job performance, in our case - effective cooperation. As psychological characteristics describing individuals involved in the cooperation we chose their propensity to trust, situational trust in teams, motivation and work engagement. Organizations have 
been characterized by their trust-building competence, which affects the process of creating favorable context for IORs. Speaking about the outcomes that companies gain from IORs, we think primarily about their multidimensional effectiveness.

To verify our hypotheses we use correlation and mediation analyses with bootstrapping, and structural equations modeling with RML (Robust Maximum Likelihood).

The remaining of the paper is divided as follows. First we present results of literature review and offer conceptual framework for the analyses, we define the constructs of organizational trust-building competence and interpersonal trust in IORs and describe their connections with the construct of work engagement, which is said to be an important antecedent of any result of people's work, which is in our case the success of inter-organizational relationship. We then describe methods used to test our hypotheses and present the results. We conclude with discussion on the results and limitations of the study.

\section{LITERATURE REVIEW}

\section{Conceptual Framework and Hypotheses Development}

\section{Trust in Inter-Organizational Relationships}

A number of studies highlight the relationship between trust and the economic results of IORs and partnering companies (Seppanen, Blomqvist \& Sundqvist, 2007; Delbufalo, 2012; Delbufalo, 2014; Ashnai, Henneberg, Naude \& Francescucci, 2015; Leszczyński, Takemura \& Zieliński, 2015; Chrupała-Pniak, Grabowski \& Sulimowska-Formowicz, 2016a, 2016b).

Trust, when understood as a form of company self-constraint in reaching own goals (and behaving opportunistically), together with the expectation that partner will reciprocate this behavior, is seen as a base for effective coordination strategy of interorganizational relations between independent market subjects. Coordination by trust is possible because trust between partners reduces uncertainty by higher predictability of partner's behavior (Sako, 1998), which in turn contributes to constructing an effective interaction on organizational and individual level (Ford, Gadde, Håkansson \& Snehota, 2011). In IORs trust is seen as a cyclic process based on negotiations, partner engagement, and execution of negotiated arrangements (Ring \& Van De Ven, 1994). Trust creates an atmosphere of open communication, information exchange and dealing with conflicts (Creed \& Miles, 1996) also critical for inter-organizational learning, which enables transformation of relational experience into RC and other core competences that determine competitive advantage of a company (Foss, 1996; Mowerym, Oxley \& Silverman, 1996; Dyer \& Singh, 1998; Zollo \& Winter, 2002; Grant, Heimeriks \& Duysters, 2007).

Dynamics of inter-organizational relationships confirms that the higher interdependence of partnering organizations, the higher the need for organizational trust. In international IORs the need for trust on organizational and individual level is especially high due to the complexity and dynamics of the environment.

\section{Trust-building Competence}

Trust is most frequently defined as trustful attitude. The researchers often focus on the declarations of trust in partner and explore the reasons for such an attitude or state of a respondent. In our approach, we focus on the sources of trust - the grounds on which a company builds both its trust and credibility in a role of business partner. The ability of 
building inter-organizational trust should support partners in eliminating cooperation risk and in effective use of opportunities and disturbances that accompany the relationship (Zaheer, Lofstrom \& George, 2003; Hakansson et al., 2009;).

According to the literature (for a review see: Nieminen, 2005a, p. 109) trust stems from three groups of determinants: process-based, characteristics-based and institutional. Process-based trust is associated with a shared history of partners and processes realized together - shared memories confirm their credibility both at the level of declarations, and according to the capacity to fulfill them. Characteristics-based trust refers to the cultural proximity of partners, shared values and established social relationships that foster shared understanding and identity between the partners. Institutional trust stems from formal confirmations that legitimize it as a partner and from its ability to build a relationship framework and create safeguards stemming from contractual and relational mechanisms. Thus to develop trust in IORS a company needs to possess specific intra- and inter-organizational capabilities and routines - its trust-building competence.

Trust-building competence is a significant part of relational competence of an organization, which we define as a bundle of attitudes, organizational routines and capabilities necessary to: establish partnership and prepare the frame for it; lead common activities and control their effects; manage knowledge creation and exchange between partners, communicate effectively, solve problems and integrate partnering firms on interorganizational, interpersonal and inter-team level (Sulimowska-Formowicz, 2015). All these competences build the ability of a firm to create and pursue effective business relationships and gain relational advantage. Some of attitudes, organizational behaviors and realized procedures that build relational competence are at the same time tools for trust building of decisive meaning to organization's credibility in the eyes of its partners. They form a basis for trusting in partner and for partners' trust. In this research we refer to inter-firm trust understood as a result of firm's semi-rational calculation of chances that the partner will behave kindly (Gambetta, 1988), not as a dispositional trait of a partner (Dasgupta, 1988). We assume that being an artifact, the organization itself cannot possess dispositional traits, which are typical only to people. We define organizational trust-building competence as equivalent of cognitive trust (Young \& Daniel, 2003; Möllering, 2006), which is formed by that set of relational competence components that: are procedural source of calculative trust, develop actor bonds and strengthen reciprocity norms on an organizational level, and support organization's credibility (ChrupałaPniak et al., 2016a, 2016b; Chrupała-Pniak \& Sulimowska-Formowicz, 2016). Organizational trust-building competence is the effect of company's experience in cooperation and its deliberate actions. It influences the result of IORs, i.e. relation efficiency and effectiveness. By stimulating the processes of relational learning it helps to develop company's competitive potential and relational competence as its part.

Thus we hypothesize that:

H1: Organizational trust-building competence predicts firms outcomes in IORs (efficiency and effectiveness). 


\section{Interpersonal Trust as Antecedents of Engagement}

Although important, organizational trust-building competence is not the only possible predictor of IORs outcomes. Another crucial factor is interpersonal trust, which influences the shaping of a favorable climate for cooperation. Interpersonal trust affects the nature of social relations both within the own, as well as partnering organizations. Research shows that interpersonal trust contributes to the strengthening of interactions in cooperation (Simpson, 2007). Organizational trust-building competence and interpersonal trust enhance creating relationships on an individual level, support effective interaction, work engagement (Hakansson et al., 2009; Ford, Gadde, Håkansson \& Snehota, 2011) and knowledge sharing inside the organization (Wu, Lin, Hsu, Yeh, 2009; Hsu $\&$ Chang, 2014). All those features influence the quality of work in teams engaged in cooperation (Paul \& McDaniel Jr., 2004; Muethel, Siebdrat \& Hoegl, 2012). Interpersonal trust, as a part of organization's social capital, may influence its outcomes through processes of identification and organizational commitment (Bakiev, 2013). Thus it plays a key role in establishing contracts (Malhotra \& Murnighan, 2002), or even contributes to individuals' health (Schneider, Konijn, Righetti \& Rusbult, 2011).

Interpersonal trust is defined as the act of vulnerability and expectation of positive intentions in the behavior of other people with whom an individual interacts (Rotter 1980; Scott 1980; Butler 1991; Gurtman 1992; Rousseau, Sitkin, Burt \& Camerer, 1998; KiffinPetersen \& Cordery 2003). It may come from both dispositional trait of a person - trust propensity, and mechanisms of interpersonal perception (situational trust). Trust propensity is a relatively stable dispositional variable shaped whit growth and with gathered experience. Interpersonal trust is also a situational variable based on calculations and affectivecognitive mechanisms, related to one's estimation of the degree of control, uncertainty and risk in social relationships and making decisions concerning interaction on this base (Simpson, 2007; Kahneman, 2011). The recent body of literature contains a lot of research reports on the role of organizational and interpersonal trust in IORs (Ashnai et al. 2013; Huang \& Wilkinson, 2013; Ashnai et. al., 2015; Delbufalo, 2014). However, the psychology of trust has not been considered much in recent conceptualizations of work engagement (Schneider, Macey, Barbera \& Young, 2010, p. 168) neither in general, nor in IOR context. There is a lack of analyses concerning relations of trust with motivation and work engagement.

One exception is the conceptualization presented by Schneider et al. (2010, p. 160), linking engagement and interpersonal trust. The level of trust that employees experience at work is seen as a psychological antecedent of employees engagement. Employees' experiences of organizational trust lead them to trust their co-workers and supervisors and the system, so they feel safe enough to engage in their work. Trust is conceptualized as the core mediating variable (Mayer, Davis \& Schoorman, 1995; Schoorman, Mayer \& Davis, 2007) in understanding employee engagement based on the model of Kahn (1990).

We suggest a new look at the job demands-resources JD-R theoretical model (Demerouti, Bakker, Nachreiner \& Schaufeli, 2001). The model integrates many dispersed studies and explains the relations between employees' psychological variables and organizational outcomes (Bakker \& Demerouti, 2007). Bakker and colleagues (2003) assumed that every occupation and organizational role may have its own specific risk factors associated with job stress and job strain which diminish the outcomes. These factors can be classified in 
two general categories: job demands and job resources. Job demands (e.g. high work pressure, emotional demands, role ambiguity etc.) may lead to several consequences that decrease effectiveness and performance. Job resources (social support, performance feedback, autonomy etc.) may foster motivational processes, engagement and organizational commitment. Reference to job characteristic model authors emphasize that job resources have a motivational potential, including autonomy, task significance, and feedback. Job resources may be located at the organizational level (pay, career opportunity, job security etc.), the interpersonal and social relations (supervisor and co-worker support, team climate), the organization of work (role clarity, participation), the level of the task (skill variety, task identity, task significance, autonomy and performance feedback). So far, trust has not been studied in this model as job or personal resources. Yet existing research suggests that individual level of interpersonal trust supports engagement and motivational processes and influences job performance (Gorgievski, Bakker \& Schaufeli, 2010; Schneider, Macey, Barbera \& Young, 2010) and organizational effectiveness (Schneider et al., 2009).

JD-R model contains two psychological processes which play role in this context. When job demands are high, individuals use performance - protection strategy. This strategy is related to physiological reaction to stress and to increasing effects of psychological and physiological costs, stemming from work overload. Individuals working under high job demands use performance - protection strategy and narrow their attention, increase selectivity, redefine task requirements and risky choices and experience subjective fatigue that in the end may influence organizational outcomes. On the other hand job resources have motivational potential and lead to boost work engagement, lower cynicism and upkeep excellent performance (Bakker \& Demerouti, 2007 ).

We assume that job demands in international IORs are relatively higher than present activities held independently, due to the greater complexity of possible joint activities, the need to adapt to partners, to reduce the psychic distance, deal with problems in the context of cultural differences and economic risks associated with both foreign market and the partner. Thus, trust propensity and autonomous motivation as personal resources and situational trust and trust building competence as job resources will affect work engagement, which predicts firms' outcomes in IORs, so we expect the following:

H2: Interpersonal trust (trust propensity and situational trust) affects work engagement in IORs.

H2a: Trust propensity as personal resource predicts work engagement in IORs.

H2b: Situational trust as job resources predicts work engagement in IORs.

H3: Organizational Trust-building competence as job resource predicts work engagement in IORs.

\section{Engagement as Psychological antecedent of Firms' Success in IORs}

In IORs actors are not only cooperating firms, but most of all people who build these social organizations. People possess social capital and capabilities potential, which may be offered at the service of companies. It is important to create favourable organizational context for the usage of personal potential, through inter- and intra-organizational mechanisms. When the potential of individuals is used accord- 
ing to the purpose of the organization, then we can talk about its effectiveness achieved thanks to controlled human resources.

In the analysis of IORs a lot of attention is paid to relations between organizational behaviors and individuals' traits and work attitudes. Relational resources most mentioned as specifically valuable in cooperation are interpersonal networks of individuals and their potential of relational skills, social or interaction skills (Walter, 1999; Ritter, 1999; Speakman et al., 2000; Phan et al., 2005; Äyväri \& Jyrämä, 2007). There is a lack of research on relationships between organizational competences and traits and attitudes of individuals, who create and use them. Thus, we decided to test the role of work engagement in this context. Work engagement is a psychological construct well-grounded both in the JD-R theory and in the evidence-based theory of work engagement and widely used in research concerning effectiveness of organizations. Many scholars present a conceptualization of work engagement as a high level of personal involvement in the job tasks performance (e.g., Kahn, 1990; Schaufeli, Salanova, Gonzalez-Roma \& Bakker, 2002; May, Gilson \& Harter, 2004; Macey \& Schneider, 2008; Rich, LePine \& Crawford, 2010). It has been praised for exploring the positive psychological resources of employees in a workplace directed towards organizational goals (Macey, Schneider, Barbera \& Young, 2009).

Among several definitions of work engagement (Albrecht, 2010; Bakker \& Leiter, 2010) the most popular is one by Schaufeli and Bakker (2004). They described work engagement as "a positive, fulfilling, work-related state of mind that is characterized by vigor, dedication, and absorption" (p. 295). Vigor implies being energetic and mentally resilient at work and being willing to invest effort and to persist when difficulties arise. Dedication means being enthusiastic and inspired at work and experiencing significance, pride, and challenge. Absorption can be described as full concentration at work and as the experience of being happy engrossed in one's work. Bakker (2011) states after Kahn (1990) that employees engaged in their work are fully connected with their work roles. Work engagement described this way is a state linked to autonomous motivation (Gagne \& Deci, 2005), which is seen as antecedent of work engagement. According to selfdetermination theory (SDT) autonomous motivation leads to work engagement (Ryan \& Deci, 2000). Autonomous regulation comprises both intrinsic motivation and the types of extrinsic motivation in which people get identified with an activity's value and ideally will integrate it into their sense of self. Thus autonomously motivated persons are really enthusiastic and interested in doing actions and behaviors. In opposite way, when people are controlled, they experience pressure to think, feel, or behave in particular ways and they experience less positive engagement and proactive behaviors. The mentioned above patterns are especially important for IORs coordinators and boundary spanners.

Saks and Gruman (2014, p. 155) state that work engagement is a key factor on organization's success and competitive advantage (Macey, Schneider, Barbera \& Young, 2009; Rich, LePine \& Crawford, 2010). Macey and colleagues (2009) found that the top of $25 \%$ on an engagement index had greater return on assets (ROA), profitability and more than double the shareholders' value compared to the engagement's bottom $25 \%$. Unfortunately, recent psychological studies on factors enhancing people's efficiency and productivity did not refer directly to the inter-organizational cooperation and its results. Engaged workers are more innovative (Gorgievski et al., 2010), spread their positive attitude toward work (Xanthopoulou, Bakker, Demerouti \& Schaufeli, 
2009) and contribute to efficiency of organization. The scholars focused mainly on selected aspects of performance measured with HRM indicators, e.g. turnover intention (Schaufeli \& Bakker, 2004; Saks, 2006; Halbesleben, 2010), task performance and contextual performance (Christian et al., 2011), and customer satisfaction, productivity, profitability, turnover and safety (Harter et. al., 2002), job performance and organizational citizenship behaviors (Saks, 2006; Rich et. al., 2010; Bakker \& Bal, 2012). Therefore, in our research we decided to look at the antecedents and consequences of engagement with the use of theoretical concepts well-grounded in psychology, i.e. the theory of evidence-based work engagement and job demands - resources theory.

Following the above reasoning we hypothesize that:

H4: Autonomous motivation as personal resource predicts work engagement in IORs.

H5: Work engagement predicts IORs results.

H6: Organizational trust-building competence, situational trust, trust propensity, and autonomous motivation influence IORs outcomes through work engagement.

\section{RESEARCH METHOD}

The research was performed on a nationwide purposive sample of 210 Polish medium and large manufacturing companies of different industries. We assumed that the larger the company, the greater the likelihood that it had developed organizational procedures. The other criterion was possessed experience in non-capital IORs and we assumed that manufacturing companies might possibly have the most diverse cooperative experience. 93\% of the sample companies cooperate constantly with foreign partners. It was impossible to obtain the number of Polish companies meeting both criteria of size and relational experience, so we aimed at obtaining a sample of structure resembling the structure of industries present in population of Polish medium and large manufacturing companies. The sample is not purely representative in statistical terms, but similar in structure to the one presented in data of Central Statistical Office of Poland (GUS, 2015), which allows us to treat the sample as some representation of Polish medium and large manufacturing companies.

The study is cross-sectional, self-descriptive and unilateral - analysis concerned characteristics of sample companies, not their partners. Within the sample we questioned 210 managers (one per company) and 982 employees in their subordinate team members (of 4-5 people each).

The applied tools were based on authors' own operationalizations of relational competence (RC) and organizational trust-building competence (O_TRUST).

$\mathrm{RC}$ is a composite variable, second order competence that consists of seven components - groups of specific competences critical on subsequent stages of IOR management: partner selection, relation planning, common activities management, integrating, problem solving, knowledge management, efficiency management. Each of these components was measured with the use of an index of routines used by companies in their IOR management processes. We used 67 items - routines grouped into seven sets corresponding to individual RC components, respondents were asked to mark those that were used regularly and then asses their quality on 5 point Likert scale. The index was calculated as a percentage of the routines used multiplied by self-assessment. Company RC 
global measure is an average of its components. Our measures of RC are indexes expressed on interval scale (1-5) (King \& Minium, 2009; Stevens, 1946).

Organizational trust-building competence (O_TRUST) is a set of 35 statements taken from RC measure that concern only procedures and behaviors connected to building inter-organizational trust before and during relation. Reliability analysis of this nominal scale showed satisfactory Cronbach's alpha coefficient of 0.78 .

RC and O_TRUST measures were based on literature and already tested operationalizations of trust and relational capabilities of organizations (Lambe, Spekman \& Hunt, 2002; Ritter, Wilkinson \& Johnston, 2002; Walter, Auer \& Ritter, 2006; Reina \& Reina, 2006; Kale \& Singh, 2007; Human \& Naude, 2009; Human, 2009; Schreiner, Kale \& Corsten, 2009; Mitrega, Ramos, Forkmann \& Henneberg, 2011). For full description of the research methods used see: (Sulimowska-Formowicz, 2015, 2016; Chrupała-Pniak et al., 2016).

Interpersonal trust (trust propensity TP) was analyzed in the context of interorganizational relationships and separately for managers (M_TP) and team members (T_TP), due to different roles the two groups play in IORs. We used two-item scale based on the concepts of Rousseau et al. (1998) and Mayer et al. (1995), similar to the items of trust used in The European Values Study EVS project. Obtained Cronbach's alpha coefficients of 0.55 (for managers' trust) and 0.63 (for teams' trust) were satisfactory for two-item scale. Interpersonal situational trust (M_ST and T_ST) was measured using the Polish adaptation of Partner Trust Questionnaire by Chang \& Lee (2013), which showed reliable with Cronbach's alpha of 0.91 .

Work engagement was analyzed with the UWES_9 - Utrecht Work Engagement Scale short version (Schaufeli et al., 2006). Motivation was tested with WEIMS_PL Work Extrinsic and Intrinsic Motivation Scale - Polish version (Chrupała-Pniak \& Grabowski, 2016a). Variables are named respectively M_UWES and M_motiv for managers and T_UWES and T_motiv for teams.

Dependent variables were cooperative relationships' results, measured with two perceptive scales of firm's effectiveness and efficiency in IORs. Effectiveness (EFFECT) was measured with 11 submeasures referring to the level of relationships' goals reaching (Zollo, Reuer \& Singh, 2002; Holtbrugge, 2004). Efficiency (EFFICIENT) was measured with 4 submeasures referring to cost, work and time efficiency and tacit resources obtaining in relations. Both scales used 5-point Likert scale. Their reliability was confirmed with Cronbach's alpha of respectively: 0.89 and 0.83 .

To test the set of hypotheses we used Statistica, SPSS.23 and LISREL software.

\section{RESULTS}

To verify the hypotheses, and answer the question about the strength of relationships between firms effectiveness and efficiency in IORs, relational competence and work engagement with motivation and trust at both individual and team level we calculated Pearson correlation coefficients (Table 1). Given the asymmetry of the distribution of variables (e.g. SKUT - EFFECT), the analysis was enriched with bootstrap analysis (Konarski, 2009). Obtained confidence intervals that do not contain zero allows us to accept the relationship as statistically significant.

As Table 1 shows, teams' work engagement (T_UWES) correlates moderately positively with their situational trust (T_ST), and intrinsic motivation (T_motiv) but moderate- 
ly negatively with intrinsic motivation of managers ( $M$ _motiv) and their commitment to work (M_UWES). Surprisingly, teams' trust and work engagement is negatively associated with work engagement of managers. Relational competence is positively but weakly related to teams' work engagement and trust propensity (T_TP), the correlation is stronger with firm's effectiveness and efficiency in IORs. A similar pattern was observed in the case of a trust-building competence: weak and positive correlation with managers' trust propensity (M_TP). The correlations of trust propensities of teams and managers are positive, but moderate and weak, with effectiveness, and only weak with efficiency.

Table 1. Correlations between variables in the research model

\begin{tabular}{|l|l|l|l|l|l|l|}
\cline { 2 - 7 } \multicolumn{1}{c|}{} & \multicolumn{1}{c|}{ EFFECT } & \multicolumn{1}{c|}{ EFFICIENT } & \multicolumn{1}{c|}{ RC } & \multicolumn{1}{c|}{ T_UWES } & \multicolumn{1}{c|}{ M_UWES } & \multicolumn{1}{c|}{ O_TRUST } \\
\hline EFFECT & & & & & & $0.320^{* * *} \mathrm{~B}$ \\
\hline EFFICIENT & $0.561^{* * \mathrm{~B}}$ & & & & & $0.226^{* * \mathrm{~B}}$ \\
\hline RC & $0.402^{* * *} \mathrm{~B}$ & $0.345^{* * *} \mathrm{~B}$ & & & & $0.846^{* * * \mathrm{~B}}$ \\
\hline T_TP & $0.281^{* * \mathrm{~B}}$ & $0.212^{* * \mathrm{~B}}$ & $0.186^{* * \mathrm{~B}}$ & $0.146^{*}$ & $-0.172^{* \mathrm{~B}}$ & $0.231^{* * \mathrm{~B}}$ \\
\hline T_ST & 0.107 & 0.074 & 0.036 & $0.515^{* * *} \mathrm{~B}$ & $-0.226^{* * \mathrm{~B}}$ & 0.023 \\
\hline T_UWES & 0.090 & 0.037 & $0.208^{* * \mathrm{~B}}$ & & $-0.353^{* * *} \mathrm{~B}$ & $0.201^{* * \mathrm{~B}}$ \\
\hline T_motiv & -0.023 & $-0.139^{* \mathrm{~B}}$ & -0.066 & $0.358^{* * *} \mathrm{~B}$ & 0.128 & -0.096 \\
\hline M_TP & $0.162^{* \mathrm{~B}}$ & 0.104 & 0.016 & -0.065 & 0.102 & $0.171^{* \mathrm{~B}}$ \\
\hline M_ST & 0.070 & 0.039 & -0.002 & -0.008 & $0.890^{* * *} \mathrm{~B}$ & -0.027 \\
\hline M_motiv & -0.022 & -0.049 & -0.107 & $-0.435^{* * *} \mathrm{~B}$ & $0.992^{* * *} \mathrm{~B}$ & -0.123 \\
\hline M_UWES & 0.002 & -0.029 & -0.086 & $-0.353^{* * *} \mathrm{~B}$ & & -0.102 \\
\hline
\end{tabular}

${ }^{* * *}-\mathrm{p}<0.001 ;{ }^{* *}-\mathrm{p}<0.01{ }^{*}-\mathrm{p}<0.05 ; \mathrm{B}$ - bootstrap analysis for 5000 samples - $95 \%$ confidence interval did not include zero.

Source: own study.

The results presented here show slightly different relationships according to managers and team members, which probably confirms different roles of those groups in executing tasks connected to IORs. Teams' trust propensity correlates weakly both with firms' effectiveness and efficiency in IORS, and also weakly with organizational variables - RC as a whole and its part - O_TRUST. Managers' trust propensity is weakly related to effectiveness and O_TRUST, without correlation neither to RC nor to firms' efficiency. Situational trust in teams weakly correlates with their trust propensity, and in case of managers we found no correlation here.

Strong correlations of situational trust with engagement proved to be in line with our expectations. This relationship seems natural and logical, because if we see colleagues as reliable, and in teams we experience trustful climate, it is more probable for us to have stronger feeling of work engagement (and it is more visible in case of managers), see: table 2 i 3.

Table 2. Correlations between trust, autonomous motivation and work engagement of teams

\begin{tabular}{|l|l|c|c|}
\cline { 2 - 4 } \multicolumn{1}{c|}{} & \multicolumn{1}{c|}{ T_TP } & T_ST & T_UWES \\
\hline T_ST & $0.193^{* * \mathrm{~B}}$ & & \\
\hline T_UWES & $0.146^{*}$ & $0.515^{* * *} \mathrm{~B}$ & $0.358^{* * \mathrm{~B}}$ \\
\hline T_motiv & $0.184^{* * \mathrm{~B}}$ & $0.395^{* * *} \mathrm{~B}$ & \\
\hline
\end{tabular}

$* * *-p<0.001 ;{ }^{* *}-\mathrm{p}<0.01 ;^{*}-\mathrm{p}<0.05 ; \mathrm{B}$ - bootstrap analysis for 5000 samples - $95 \%$ confidence interval did not include zero.

Source: own study. 
As presented in Table 3, situational trust, autonomous motivation and work engagement of managers are strongly correlated, and an exception here is managers' trust propensity (M_TP) not correlated to other variables of this level.

Table 3. Correlations between trust, autonomous motivation and work engagement of managers

\begin{tabular}{|c|c|c|c|}
\hline & M_TP & M_ST & M_motiv \\
\hline M_ST & 0.029 & & \\
\hline M_motiv & 0.085 & $0.734^{* * *} \mathrm{~B}$ & \\
\hline M_UWES & 0.096 & $0.826^{* * *} \mathrm{~B}$ & $0.989^{* * *}$ в \\
\hline
\end{tabular}
not include zero.

Source: own study.

Strong correlations between M_ST, M_motiv and M_UWES (table 3) made us decide to combine those variables into one called the role of managers (MANROLE).

In the next step of analysis we built regression models (table 4), with work engagement of teams as dependent variable and as independent variables: organizational trust and individual dimensions of teams' trust, autonomous motivation of teams, trust propensity of managers and role of managers (MANROLE).

Table 4. Work engagement predictors

\begin{tabular}{|c|c|c|c|c|}
\hline \multirow{2}{*}{$\begin{array}{l}\text { Models: (dependent variable) } \\
\text { modules: (independent variables) }\end{array}$} & \multicolumn{4}{|c|}{ Teams' work engagement (T_UWES) } \\
\hline & 1. ${ }^{a}(B)$ & 2.( $(6)$ & 3.( 6$)$ & 4. ( 6$)$ \\
\hline O_TRUST & $0.17^{*}$ в & $0.22^{* * * B}$ & $0.22^{* * * B}$ & $0.21^{* * * B}$ \\
\hline T_TP & 0.12 & -0.02 & 0.00 & -0.05 \\
\hline T_ST & & $0.43^{* * * B}$ & $0.42^{* * *} \mathrm{~B}$ & $0.38^{* * * B}$ \\
\hline T_motiv & & $0.22^{* * * \mathrm{~B}}$ & $0.22^{* * * B}$ & $0.27^{* * * \mathrm{~B}}$ \\
\hline M_TP & & & -0.06 & -0.02 \\
\hline MANROLE & & & & $-0.24^{* * * B}$ \\
\hline $\mathrm{F}$ & $5.58^{* *}$ & $25.39^{* * *}$ & $20.46^{* * *}$ & $21.10^{* * *}$ \\
\hline $\mathrm{R}^{2}$ & 0.05 & 0.34 & 0.34 & 0.39 \\
\hline $\mathrm{SR}^{2}$ & 0.04 & 0.33 & 0.33 & 0.38 \\
\hline$\Delta R^{2}$ & 0.05 & 0.29 & 0.00 & 0.05 \\
\hline $\mathrm{F} \Delta \mathrm{R}^{2}$ & $5.58^{* *}$ & $42.84^{* * *}$ & 0.83 & $16.27^{* * *}$ \\
\hline
\end{tabular}

Modules of independent variables: 1. O_TRUST and T_TP.; 2. O_TRUST, T_TP, T_ST and T_motiv; 3. O_TRUST, T_TP, T_ST, T_motiv and M_TP; 4. O_TRUST, T_TP, T_ST, T_motiv, M_TP and MANROLE.

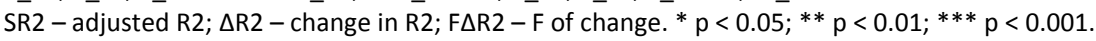

Source: own study.

Table 4 shows that predictors of teams' work engagement are: organizational trust-building competence, situational trust and autonomous motivation. Also managers' traits, that build MANROLE variable predict teams work engagement. All those variables explain c.a. 38\% variance of teams' work engagement, and team traits alone (MANROLE excluded) explain 33\% variance of the variable.

Then we held mediation analyses (see Preacher \& Hayes, 2004) with teams' work engagement as dependent variable and all dimensions of trust as independent variables mediated by autonomous motivation. In relationship of teams engagement with their trust propensity, mediation is complete, but in relationship with situational trust mediation is 
partial. We also analyzed relationships between teams' work engagement and firms' effectiveness and efficiency in IORs, where relational competence mediates completely.

Next step in the mediation analysis was SEM analysis. Estimation of models' fit was based on RMSEA (Root Mean Square Error of Approximation), CFI (Comparative Fit Index), SRMR (Standardized Root Mean Square Residual) and NFI (Normed Fit Index) coefficients (Schermelleh-Engel, Moosbrugger, Müller, 2003; Lim et al., 2007). Because of far from normal distribution of some of variables we used ML (Maximum Likelihood) and RML (Robust Maximum Likelihood) estimators. Result of SEM modeling are shown in Figures 1, 2, 3. We analyzed several models and only those with the best fit are presented here.

The best fitting model (Table 1) shows path in which teams' traits: T_ST and T_motiv together with managers' traits: MANROLE predict teams' work engagement T_UWES, which in turn predicts firms' effectiveness (EFFECT) in IORs but fully mediated by relational competence RC. In this model teams' trust propensity predicts effectiveness directly. Explained variance: effectiveness - 19\%, RC- 5\% and T_UWES - 35\%.

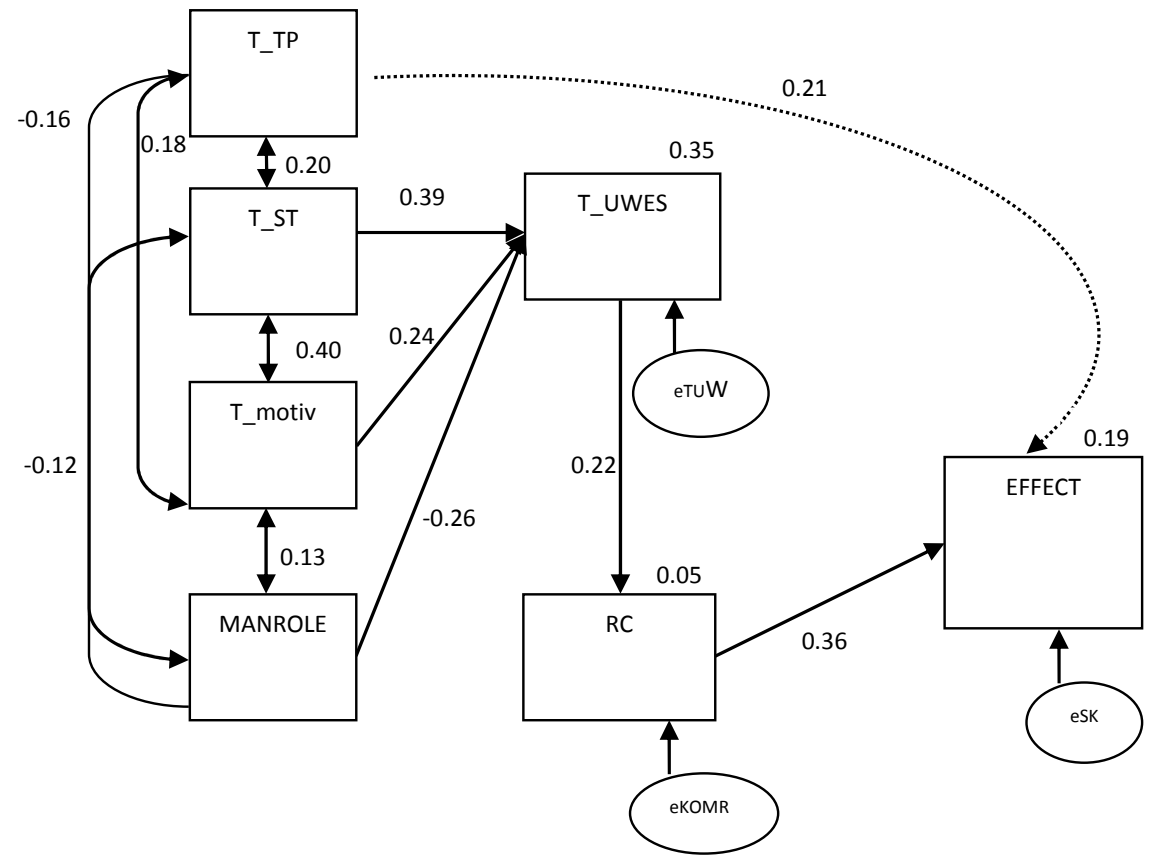

Figure 1. The best fitting model - path explaining effectiveness with T_UWES and RC as mediators

$\chi^{2}(d f)=17,04(9)(p<0,05), \chi^{2} / d f=1,89 ; \overline{R M S E A}=0,068 ; \mathrm{CFI}=0,96 ; \mathrm{NFI}=0,93 ; \mathrm{SRMR}=0,049 ; \mathrm{GFI}=0,98$. All correlation and path coefficients above 0.13 relevant with 0,05 .

Source: own studies.

According to our aim to verify the role of trust-building competence in firms' outcomes in IORs we built other models. Analyses made us decide about excluding O_TRUST from the other job resources and we treated this variable as an outcome of work engagement. One of them showed to be on the border of a satisfactory fit. In that model teams' traits: situational trust T_ST and motivation T_motiv together 
with managers' traits grouped in MANROLE variable predict teams' work engagement, which then predicts effectiveness, but fully mediated by organizational trustbuilding competence O_TRUST. Teams' trust propensity T_TP also predict effectiveness mediated by O_TRUST, which confirms role of both those variables. Explained variance: effectiveness - 10\%, O_TRUST - $8 \%$ and T_UWES - 35\%.

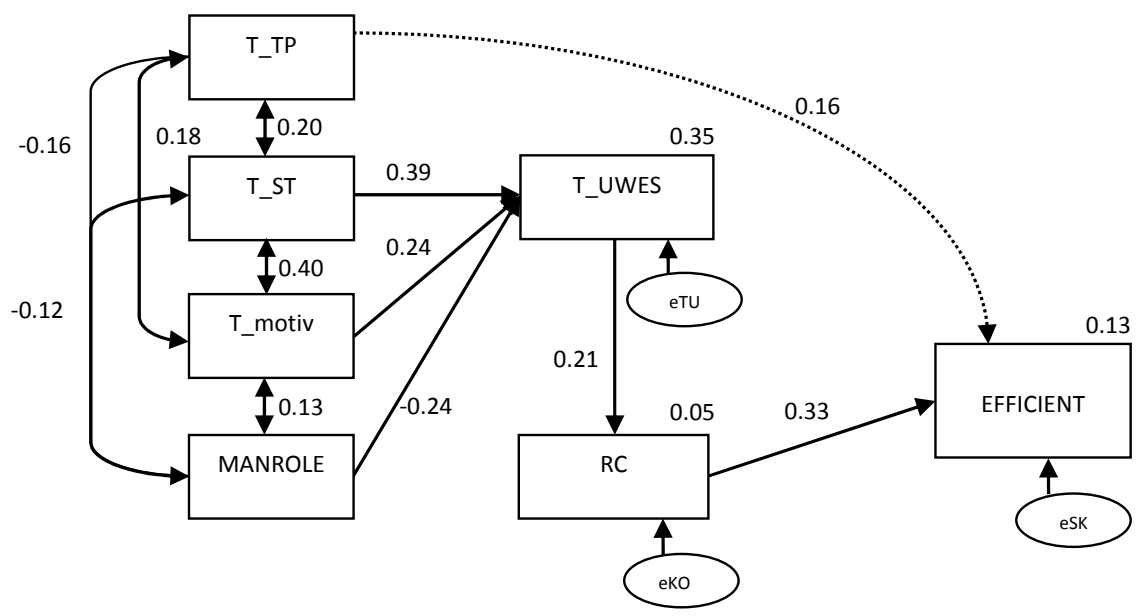

Figure 2. Model of satisfactory fit - path explaining efficiency with T_UWES and RC as mediators $\chi^{2}(d f)=21,01(9)(\mathrm{p}<0,05), \chi^{2} / d f=2,33 ; \mathrm{RMSEA}=0,082 ; \mathrm{CFI}=0,94 ; \mathrm{NFI}=0,90 ; \mathrm{SRMR}=0,058 ; \mathrm{GFI}=0,97$.

All correlation and path coefficients above 0,13 relevant with 0,05 .

Source: own studies.

Model testing similar path but with efficiency as dependent variable showed poor fit to data.

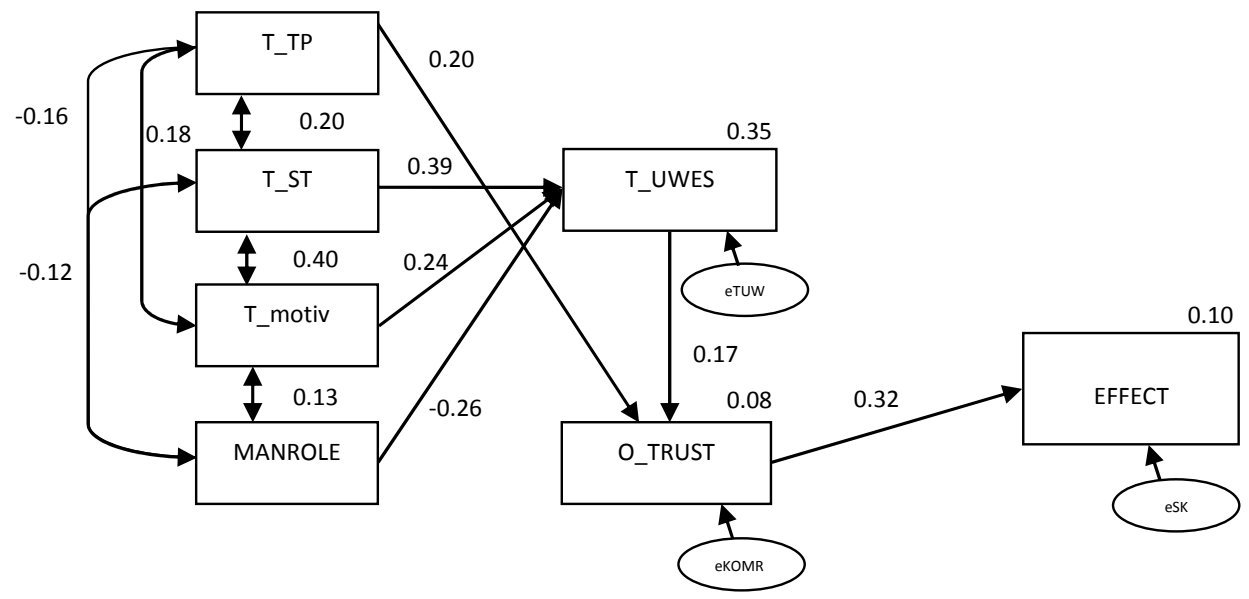

Figure 3. . Model on the border of satisfactory fit - teams' traits with managers' traits predict work engagement, which predicts effectiveness fully mediated by O-TRUST

$\chi^{2}(d f)=26,22(9)(p<0,05), \chi^{2} / d f=2,91 ; \mathrm{RMSEA}=0,099 ; \mathrm{CFI}=0,91 ; \mathrm{NFI}=0,88 ; \mathrm{SRMR}=0,061 ; \mathrm{GFI}=0,97$.

All correlation and path coefficients above 13 relevant with 0,05 .

Source: own studies. 


\section{DISCUSSION}

The results partially confirmed all our theoretical assumptions and hypotheses and we contribute to the analyses of relations of trust with individuals' motivation and work engagement that affects firms' success in inter-organizational relations'. Assumptions made on the basis of JD-R model were mostly confirmed according to teams' work engagement. In case of managers three variables: situational trust, autonomous motivation and work engagement are strongly correlated, which suggests them to be one aggregated variable important job resource, which, although not present in our theoretical model in that form, finally showed to be an important predictor of teams' work engagement.

The issue of relationships between psychological characteristics and firms outcomes in IORs still remains uncovered. Our analyses confirmed effect of work engagement on IORs results, although not direct (as we assumed in theoretical model), but mediated by relational competence or trust building competence as its component. This suggests that for the sake of interdisciplinary research on organizational and personal variables in the evidence based model of work engagement, it is necessary to make a distinction between proximal and distal consequences or outcomes. We propose that the proximal outcome of work engagement in IORs may be development of organizational competences, which when used affect distal outcome of reaching goals efficiently.

Regression and mediation analyses that we held confirmed almost all hypotheses: $\mathrm{H} 1, \mathrm{H} 2 \mathrm{a} ; \mathrm{H} 2 \mathrm{~b} ; \mathrm{H} 3 ; \mathrm{H} 4$, but on team level. Mediation analysis confirmed also H5. H6 was not confirmed. We found other path explaining dependent variables. Our study shows that job and personal resources, i.e. interpersonal trust, organizational trustbuilding competence and motivation influence work engagement of IORs' tasks executors. The role of manager (MANROLE) appeared as a new job resource predicting teams engagement. According to the results of regression analysis the variance of explained work engagement rises from 33\% without MANROLE, to 39\% when added to the model. What should be stressed here, we did not control other job resources as e.g. managers' support, work climate or job demands.

Because we combined variables associated with managers into a new complex one, and included it into the model testing hypotheses on team level, we gave up testing another model for managers. We assume that this situation stems from the specifics of organizational roles that task executors play in IORs. Managers work as both inter-organizational boundary spanners, and also as supervisors of teams controlling their work results. It is probably the reason why we confirmed negative relationship between motivation and work engagement of managers and their subordinates in teams. The more manager is involved in his role as supervisor using available modes of influence / pressure on team members, the less autonomously motivated, and so engaged are the teams members. According to the paradigm of positive psychology we decided to measure personal traits through the lenses of autonomous regulation, which is most sensitive to external regulation (Ryan \& Deci, 2000), so our approach partially explains obtained results.

The relation of people's self-regulation with trust can be explained by fulfilling the need of relatedness with other people that in turn increases both dimensions of trust (Deci \& Ryan, 2008). Simultaneously, this regulation directly, and indirectly increases all the dimensions of work engagement (dedication, absorption and vigor). On the 
other hand, situational trust then enhances people's faith in own competences and gives them autonomy supporting work engagement.

We assume that research on management styles would bring additional valuable results to our approach. If we presume, on the basis of available research on managing styles, that in Polish companies still directive and autocratic styles dominate over the consultative and participative ones, we may think that this gives an explanation to our observations. Differences in the strength of relationships between motivation and work engagement and situational trust of managers and teams confirm earlier studies (Chrupała-Pniak et al., 2016).

We find the observed negative and weak relationship of autonomous motivation with firm's efficiency in IORs interesting and worth deeper analyses. We suppose that autonomous motivation will always be negatively connected with such a work results criterion. By definition, efficiency reaching is seen as one of different restrictions of intrinsic motivation, among e.g. time pressure, norms, costs and as such will always be positively related to extrinsic motivation (e.g. financial). We think that our observation is an important contribution to the body of knowledge on autonomous motivation.

Additionally, we may presume that cooperation will be productive, with long-lasting positive outcomes when they are induced by mechanisms of autonomous motivation, commonly considered as more valuable than controlled motivation. As so this is also of meaning for managerial purposes. Organizational motivation systems related to results of workers' efforts, enhance their sense of own competences, autonomy and increase their work engagement. Motivation system, when used improperly may also weaken autonomous motivation and turn it into controlled, so managers should more openly use non material motivation instruments, respect workers for their efforts, create tasks in order to fulfill the needs that build their self-determination. These practices affect work climate, situational trust and in broader sense the atmosphere of IOR. In the context of IORs' these practices are also building blocks of organizational trust-building and relational competence and should fit the requirements of successful relation management process. In international IORs one should also pay attention to cross-cultural determinants of both inter-organizational competences and successful motivational systems.

According to the trust-building competence this research shows that the idea of this variable we used does not fit to our assumptions of its role in JD-R model. Organizational trust with situational trust are weak predictors of work engagement (only $5 \%$ explained variance). SEM analysis confirmed that organizational trust is more the outcome than the antecedent of work engagement. As we could not include it into the models of good or satisfactory fit, we are unable to clearly state that it is a job resource predicting work engagement. Although we know that this variable correlates weakly with teams engagement and trust propensity of both managers and teams, probably because of the measurement procedure that we used according to this variable, it may not be seen as job resource in JD$\mathrm{R}$ model. Satisfactory fit was confirmed for the models in which O-TRUST and RC predict firms' outcomes in IORs and serve more as outcomes of work engagement, than its antecedents. Nevertheless our results does not undervalue the meaning of the variable itself.

Our approach to RC and trust-building competence measurement gives us an insight into organizational procedures and capabilities usage and self-assessment. The results show that firms' outcomes in IORs depend on how employees' motivation and work engagement influence the usage of organizational competences, e.g. those necessary for 
effective inter-partner communication and integration or learning in IORs. People with low work engagement may not be willing to use organizational potential properly, e.g. omit some inconvenient procedures, so we may assume that it is not the quality of RC or trust-building competence that predicts outcomes in IOrs, but personal work engagement is decisive to the way those resources are used and developed.

Our observation of the preceding role of work engagement in turning organizational competences into positive outcomes in IORs develops the results of other research offering rationalizations for the necessary level of development of relational competences. Research on absorptive capacity or trust instruments reveal that above some critical level this investment may be counterproductive due to growing costs of coordination of those instruments exceeding possible gains (Luo, 2008; Wales, Parida \& Patel, 2013). Although our research does not explain this situation, it points at other aspect of the case. As interpersonal trust, motivation and work engagement predict firms outcomes in IORs but mediated by RC or trust building competence, companies should think about the balance between investments in organizational competences and developing desirable traits and states of their employees. It also may be advisable to managers of companies, especially those less experienced in IORs or less developed, or small, to fill this gap in resources by supporting people and their interpersonal talents and professionalism and boost their work engagement by trust-building and motivational tools.

Although situational trust, seen as job resource according to JD-R model, is not connected to firms' outcomes in IORs and to RC, it is strongly related to teams' and managers' work engagement. It is thus visible that interpersonal trust among IORs' goals executors is an important asset, shaping work engagement of cooperators. We find interesting the strong negative correlation of situational trust of teams with work engagement of their managers, and similarly strong negative correlation of UWES of the two groups. According to the theorizing of positive psychology, positive states should disperse among individuals in work environment and in our case we have a contradictory observation. Our research does not give us the possibility to explain this phenomenon, but we may assume that it could be situationally and culturally grounded. As mentioned above, dominance of authoritarian management style may be visible in manager's attitude - less engaged, more supervising, delegating responsibilities on direct executors. Sometimes this situation may be also be an effect of work overload of managers who concentrate their actions on building effective teams, which enables them to withdraw direct involvement and turn attention to other responsibilities.

Finally we shall mention about some limitations of our approach and directions for further research.

Our research is cross-sectional and based on self-assessment, so it would be of value to supplement them with other measures of the variables, e.g. behavioral and use longitudinal study with repeated measurements. Longitudinal study would also help to understand better possible changes in observed phenomena at subsequent stages of IORs. We also did not control broader context of work engagement, which may be affected by more factors and change over time. Among other influencing contextual variables worth further research in context of building trust and work engagement in IORs is managerial style. As our results show important role of managerial traits' influence, it would be of 
value to deepen the analysis by combining them with research of managerial style context also in IORs. There is a lack of research in this topic.

Researchers highlight the importance of other psychological traits like individual entrepreneurial orientation so there is an open valley to multivariable analyses with richer sets of psychological factors determining firm results In IORs and the context of IORs.

We also suggest the need for further research according to relationships between work engagement and personal traits and different components of trust-building competence and relational competence of organization, as we assume that they may differ in strength and direction, as well as their explanatory power for IORs results. Deeper knowledge on these phenomena might be of practical value for firms and their efforts in developing relational competences and work environment for employees.

As our research confirms important interconnections between IORs success determinants on organizational, team and individual levels, we suggest the need for further multilevel analyses.

\section{CONCLUSIONS}

This study contributes to inter-organizational relations literature in management by showing the multilevel and multifactor character of relationships between the antecedents of firms success in IORs. Our analyses confirmed positive role of both organizational competences (trust-building and relational competence) and psychological states of individuals (work engagement), as valuable mediators in translating the potential of personal traits (interpersonal trust, autonomous motivation) of teams and managers into IORs outcomes (effectiveness and efficiency). This indicates the need for more interdisciplinary studies, especially combining the lenses of organization science, and sociology with psychology, which is rather rare.

Our findings give also some managerial implications. More attention paid to psychological aspects and joint analyses of their managerial consequences may help to develop more effective HR tools in shaping IORs (Pucik, 2009). When constructing motivational systems companies should remember about necessary balance between tools affecting efficiency aspects and those determining intrinsic motivation and work engagement, especially in the long run. Tools connected with efficiency negatively affect work engagement and its personal antecedents, which may diminish people's effectiveness as IOR coordinators and boundary spanners and push them to behave opportunistically. HRM tools and managerial practices should also be shaped taking into account differences in in-role characteristics and effectiveness of managers and cooperating team members. For people training and development purpose, our results suggest that companies should search for balance between developing necessary relational skills and creating work atmosphere and (inter-)organizational culture enhancing work engagement, interpersonal trust and autonomous motivation.

By developing strong organizational trust-building competence and relational competence as a whole, companies equip workers with safeguards helpful in effective usage of their own potential of work engagement. On the other hand for firms with less competent in managing IORs, social capital of workers may be used to cover those deficits (for more see: Chrupała-Pniak et. al., 2016). 


\section{REFERENCES}

Albrecht, S.L. (2010). Handbook of Employee Engagement. Perspectives, Issues, Research and Practice. New Horizon in Management. Northampton: Edward Elgar.

Ashnai, B., Henneberg, S., Naudè, P., \& Francescucci, A. (2016). Inter-personal and interorganizational trust in business relationships: An attitude-behavior-outcome model. Industrial Marketing Management, 52, 128-139.

Ashnai, B., Henneberg, S., \& Naudè, P. (2013). An Attitude-Behavior-Outcome Framework of Business-To-Business Relationships: Distinguishing Between Inter-Personal Trust and InterOrganizational Trust. Proceedings of the 29th IMP Conference, Atlanta, Georgia, USA.

Äyväri, A., \& Jyrämä, A. (2007). The Networking Abilities of Craft Entrepreneurs. Proceedings of the 23rd IMP Conference, Manchester, UK.

Bakiev, E. (2013). The Influence of Interpersonal Trust and Organizational Commitment on Perceived Organizational Performance. Journal of Applied Economics and Business Research, 3(3), 166-180.

Bakker, A.B., \& Bal, M.P. (2010). Weekly work engagement and performance: A study among starting teachers. Journal of Occupational and Organizational Psychology, 83(1), 189-206.

Bakker, A.B., \& Demerouti, E. (2007). The Job Demands-Resources model: state of the art. Journal of Managerial Psychology, 22(3), 309-328.

Bakker, A.B., \& Demerouti, E. (2014). Job Demands-Resources Theory. Wellbeing, 3, 1-28.

Bakker, A.B., Demerouti, E., De Boer, E., \& Schaufeli, W.B. (2003). Job demands and job resources as predictors of absence duration and frequency. Journal of Vocational Behavior, 62, 341-356.

Bakker, A.B., \& Leiter, M.P. (2010). Work Engagement: A Handbook of Essential Theory and Research. Abingdon: Taylor And Francis Group Psychology Press.

Bakker, A.B. (2011). An Evidence-Based Model of Work Engagement. Current Directions in Psychological Science, 20(4), 265-269.

Butler, J.K. (1991). Toward Understanding and Measuring Conditions of Trust: Evolution of a Conditions of Trust Inventory. Journal of Management, 17(3), 643-663.

Carson, S.J., Madhok, A., \& Tao, W. (2006). Uncertainty, opportunism, and governance: The effects of volatility and ambiguity on formal and relational contracting. Academy of Management Journal, 49(5), 1058-1077.

Christian, M.S., Garza, A.S., \& Slaughter, J.E. (2011). Work engagement: A quantitative review and test of its relations with task and contextual performance. Personnel Psychology, 64(1), 89-136.

Chrupała-Pniak, M., Grabowski, D. (2016a). Etyka pracy, przywiązanie organizacyjne a gotowość do podejmowania nieetycznych zachowań proorganizacyjnych: raport z badań. Psychologia Społeczna, 1(36), 69-83.

Chrupała-Pniak, M., \& Grabowski, D. (2016b). Skala motywacji zewnętrznej i wewnętrznej do pracy (WEIMS-PL). Wstępna charakterystyka psychometryczna polskiej wersji kwestionariusza Work Extrinsic and Intrinsic Motivation Scale. Psychologia Społeczna, 3(38), 339-355.

Chrupała-Pniak, M., Grabowski, D., \& Sulimowska-Formowicz, M. (2016). The value of trust in interorganizational relations. Economics and Business Review, 16(2), 127-143.

Creed, D., \& Miles, E. (1996). Trust in Organizations. A Conceptual Framework Linking Organizational Forms, Managerial Philosophies, and the Opportunity Costs of Control. In R.M. Kramer \& T. Tyler (Eds.), Trust in organizations. Frontiers of Theory and Research (pp. 1638). London: Thousand Oaks: Sage Publications. 
Das, T.K., \& Rahman, N. (2010). Determinants of partner opportunism in strategic alliances: A conceptual Framework. Journal of Business and Psychology, 25(1), 55-74.

Dasgupta, P. (1988). Trust as a commodity. In D. Gambetta (Ed.), Trust, Making and Breaking Cooperative Relations (pp. 49-72). Oxford, New York: Basil Blackwell.

Deci, E.L., \& Ryan, R.M. (2008). Facilitating optimal motivation and psychological well-being across life's domains. Canadian Psychology/Psychologie Canadienne, 49(1), 14-23.

Delbufalo, E. (2012). Outcomes of inter-organizational trust in supply chain relationships: a systematic literature review and a meta-analysis of the empirical evidence. Supply Chain Management-An International Journal, 17(4), 377-402.

Delbufalo, E. (2014). Subjective trust and perceived risk influences on exchange performance in supplier-manufacturer relationships. Scandinavian Journal of Management, 31(1), 84-101.

Demerouti, E., Bakker, A.B., Nachreiner, F., \& Schaufeli, W.B. (2001). The Job Demands-Resources Model of Burnout. Journal of Applied Psychology, 86(3), 499-512.

Dirks, K.T. (2006). Three Fundamental Questions Regarding Trust in Leaders. In R. Bachmann \& A. Zaheer (Eds.), Handbook of Trust Research (pp. 15-28). Cheltenham: Edward Elgar Publishing.

Dyer, J.H., \& Singh, H. (1998). The Relational View: Cooperative Strategy and Sources of Interorganizational Competitive Advantage. Academy of Management Review, 23, 660-679.

Fink, M., Kessler, A., \& RößI, D. (2007). Trusting champions how trust based inter-firm cooperation boosts firm performance. Conference proceedings: 2007 International Conference Enterprise in Transition (pp. 1-16). Split: Ekonomski Fakultet Sveucilista u Splitu.

Ford, D., Gadde, L., Håkansson, H., \& Snehota, I. (2011). Managing Business Relationships. Chichester: John Wiley \& Sons Ltd.

Foss, N.J. (1996a). Knowledge-Based Approaches to the Theory of the Firm: Some Critical Comments. Organization Science, 7(5), 470-476.

Foss, N.J. (1996b). More Critical Comments on Knowledge-Based Theories of the Firm. Organization Science, 7(5), 519-523.

Gagne, M., \& Deci, E.L. (2005). Self-determination theory and work motivation. Journal of Organizational Behavior, 26, 331-362.

Gambetta, D. (Ed.). (1988). Trust: Making and Breaking Cooperative Relations. New York: Basil Blackwell.

Gorgievski, M.J., Bakker, A.B., \& Schaufeli, W.B. (2010). Work engagement and workaholism: comparing the self-employed and salaried employees. The Journal of Positive Psychology, 5(1), 83-96.

Grant, R.M. (1996). Toward a Knowledge-Based Theory of the firm. Strategic Management Journal, 13, $135-144$.

Gurtman, M.B. (1992). Trust, distrust, and interpersonal problems: A circumplex analysis. Journal of Personality and Social Psychology, 62(6), 989-1002.

Hakansson, H., Ford, D., Gadde, L., Snehota, I., \& Waluszewski, A. (2009). Business in Networks. Chichester: John Wiley \& Sons Ltd.

Halbesleben, J.R.B. (2010). A meta-analysis of work engagement: Relationships with burnout, demands, resources, and consequences. In A.B., Bakker, \& M.P. Leiter (Eds.), Work Engagement: A Handbook of Essential Theory and Research (pp. 102-117). New York: Taylor And Francis Group Psychology Press.

Harter, J.K., Schmidt, F.L., \& Keyes, C.L. (2002). Well-Being in the Workplace and its Relationship to Business Outcomes: A Review of the Gallup Studies. In C.L. Keyes \& J. Haidt (Eds.), Flouring: The Positive Person and the Good Life (pp. 205-224). Washington: American Psychological Association. 
Heimeriks, K.H., Duysters, G. (2007). Alliance capability as a mediator between experience and alliance performance: An empirical investigation into the alliance capability development process. Journal of Management Studies, 44, 25-49.

Holtbrugge, D. (2004, May-June). Management of International Strategic Business Cooperation: Situational Conditions, Performance Criteria, and Success Factors. Thunderbird International Business Review, 46(3), 255-274.

Hsu, M.H., \& Chang, C.M. (2014). Examining interpersonal trust as a facilitator and uncertainty as an inhibitor of intra-organisational knowledge sharing. Information Systems Journal, 24(2), 119-142.

Huang, Y., \& Wilkinson, I.F. (2013). The dynamics and evolution of trust in business relationships. Industrial Marketing Management, 42(3), 455-465.

Human, G. (2009). Measuring Network Competence in Buyer-supplier Relationships. South African Journal of Economic and Management Studies, NS 12(4), 429-447.

Human, G., \& Naudé, P. (2009). Exploring the relationship between network competence, network capability, and firm performance: a resource based perspective in an emerging economy. Management Dynamics, 18(1), 2-14.

Kahn, W.A. (1990). Psychological Conditions of Personal Engagement and Disengagement at Work. Academy of Management Journal, 33(4), 692-724.

Kahneman, D. (2011). Thinking Fast and Slow (Polish Edi). Poznań: Media Rodzina.

Kale, P., \& Singh, H. (2007). Building firm capabilities through learning: The role of the alliance learning process in alliance capability and firm-level alliance success. Strategic Management Journal, 28(10), 981-1000.

Kiffin-Petersen, S., \& Cordery, J. (2003). Trust, individualism and job characteristics as predictors of employee preference for teamwork. International Journal of Human Resource Management, 14(1), 93-116.

Kim, P.H., Dirks, K.T., \& Cooper, C.D. (2009). The Repair of Trust: A Dynamic Bilateral Perspective and Multilevel Conceptualization. Academy of Management Review, 34(3), 401-422.

King, B.M., \& Minium, E.W. (2009). Statystyka dla psychologów i pedagogów. Warszawa: Wydawnictwo Naukowe PWN.

Lambe, C.J., Spekman, R.E., \& Hunt, S.D. (2002). Alliance Competence, Resources, and Alliance Success: Conceptualization, Measurement, and Initial Test. Journal of the Academy of Marketing Science, 30(2), 141-158.

Leszczyński, G., Takemura, M., \& Zieliński, M. (2015). Trust in Business to Business Relationships. Meidai Shogaku Ronso, 99, 33-49.

Lim, D.H., Woehr, D.J., You, Y.M., \& Gorman, C.A. (2007). The Translation and Development of a Short Form of the Korean Language Version of the Multidimensional Work Ethic Profile. Human Resource Development International, 10, 319-331.

Luo, Y. (2008). Structuring inter-organizational cooperation: the role of economic integration in strategic alliances. Strategic Management Journal, 29, 617-637.

Macey, W.H., \& Schneider, B. (2008). Engaged in engagement: We are delighted we did it. Industrial and Organizational Psychology, 1(1), 76-83.

Macey, W.H., Schneider, B., Barbera, K.M., \& Young, S.A. (2009). Employee Engagement: Tools for Analysis, Practice, and Competitive Advantage. New York: Wiley-Blackwell Publication.

Malhotra, D., \& Murnighan, J.K. (2002). The effects of contracts on interpersonal trust. Administrative Science Quarterly, 47, 534-559. 
May, D.R., Gilson, R.L., \& Harter, L.M. (2004). The psychological conditions of meaningfulness, safety and availability and the engagement of the human spirit at work. Journal of Occupational and Organizational Psychology, 77(1), 11-37.

Mayer, R.C., Davis, J.H., \& Schoorman, F.D. (1995). An integration model of organizational trust. Academy of Management Review, 20(3), 709-734.

Mitrega, M., Ramos, C., Forkmann, S., \& Henneberg, S.C. (2011). Networking capability, networking outcomes, and company performance: A nomological model including moderation effects. Proceedings of the 27th Annual Conference of the IMP Group, Glasgow, UK.

Möllering, G. (2006). Trust, institutions, agency: towards a neoinstitutional theory of trust. In R. Bachmann \& A. Zaheer (Eds.), Handbook of Trust Research (pp. 355-376). Cheltenham: Edward Elgar.

Mowery, D.C., Oxley, J.E., \& Silverman, B.S. (1996). Strategic alliance and interfirm knowledge transfer. Strategic Management Journal, 17, 77-91.

Muethel, M., Siebdrat, F., \& Hoegl, M. (2012). When do we really need interpersonal trust in globally dispersed new product development teams? R\&D Management, 42(1), 31-46.

Nieminen, H.T. (2005). Successful Inter-Organizational Knowledge Transfer: Developing PreConditions through the Management of the Relationship Context. The Electronic Journal of Knowledge Management, 3(2), 107-118. Retrieved on November 6, 2016 from: www.ejkm.com

Paul, D.L., \& McDaniel Jr., R.R. (2004). A field study of the effect of interpersonal trust on virtual collaborative relationship performance. MIS Quarterly, 28(2), 183-227.

Phan, M.C.T., Styles, C.W., \& Patterson, P.G. (2005). Relational competency's role in Southeast Asia business partnerships [Special issue]. Journal of Business Research, 58(2), 173-184.

Preacher, K.J., \& Hayes, A.F. (2004). SPSS and SAS procedures for estimating indirect effects in simple mediation models. Behavior Research Methods. Instruments and Computers, 36, 717-731.

Provan, K.J., \& Skinner, J. (1989). Interorganizational dependence and control as predictors of opportunism in dealer-supplier relations. Academy of Management Journal, 32, 202-212.

Pucik, V. (2009). Strategic aliances with the Japanese: implications for human resource management. In F.J. Contractor \& P. Lorange (Eds.), Cooperative strategies in international business (pp. 487-498). Bingley: Emerald.

Reina, D.S., \& Reina, M.L. (2006). Trust and Betrayal in the Workplace Building Effective Relationships in Your Organization. Oakland: Berrett-Kohler.

Rich, B.L., LePine, J.A., \& Crawford, E.R. (2010). Job Engagement: Antecedents and effects on job performance. Academy of Management Journal, 53(3), 617-635.

Ring, P.S., \& Van De Ven, A.H. (1994). Developmental Processes of Cooperative Interorganizational Relationships. Academy of Management Review, 19(1), 90-118.

Ritter, T. (1999). The Networking Company. Industrial Marketing Management, 28, 467-479.

Ritter, T., Wilkinson, I.F., \& Johnston, W.J. (2002). Measuring network competence: some international evidence. Journal of Business and Industrial Marketing, 17, 119-138.

Rotter, J.B. (1980). Interpersonal trust, trustworthiness, and gullibility. American Psychologist, 35(1), 1-7.

Rousseau, D.M., Sitkin, S., Burt, R.S., \& Camerer, C. (1998). Not so different at all: A crossdisciplinary view of trust. Academy of Management Review, 23, 393-404.

Ryan, R., \& Deci, E. (2000). Intrinsic and Extrinsic Motivations: Classic Definitions and New Directions. Contemporary Educational Psychology, 25(1), 54-67.

Saks, A.M. (2006). Antecedents and consequences of employee engagement. Journal of Managerial Psychology, 21(7), 600-619. 
Saks, A.M., \& Gruman, J.A. (2014). What Do We Really Know About Employee Engagement?. Human Resource Development Quarterly, 25(2).

Sako, M. (1998). Does trust improve business performance?. In C. Lane \& R. Backman (Eds.), Trust within and between organizations: Conceptual issues and empirical application (pp. 88-117). Oxford: Oxford University Press.

Sako, M., \& Helper, S. (1998). Determinants of trust in supplier relations: Evidence from the automotive industry in Japan and the United States. Journal of Economic Behavior \& Organization, 34(3), 387-417.

Schaufeli, W.B., \& Bakker, A.B. (2004). Job demands, job resources, and their relationship with burnout and engagement: A multi-sample study. Journal of Organizational Behavior, 25(3), 293-315.

Schaufeli, W.B., Bakker, A.B., \& Salanova, M. (2006). The Measurement of Short Questionnaire A Cross-National Study. Educational and Psychological Measurement, 66(4), 701-716.

Schaufeli, W.B., Salanova, M., González-Romá, V., \& Bakker, A.B. (2002). The Measurement of Engagement and Burnout: A Two Sample Confirmatory Factor Analytic Approach. Journal of Happiness Studies, 3, 71-92.

Schermelleh-Engel, K., Moosbrugger, H., \& Mülle, H. (2003). Evaluating the Fit of Structural Equation Models: Tests of Significance and Descriptive Goodness-of-Fit Measures. Methods of Psychological Research Online, 8, 23-74.

Schlenker, B.R., Helm, B., \& Tedeschi, J.T. (1973). The effects of personality and situational variables on behavioral trust. Journal of Personality and Social Psychology, 25(3), 419-427.

Schneider, I.K., Konijn, E.A., Righetti, F., \& Rusbult, C.E. (2011). A healthy dose of trust: The relationship between interpersonal trust and health. Personal Relationships, 18(4), 668-676.

Schneider, B., Macey, W.H., Barbera, K.M., \& Young, S.A. (2010). The role of employee trust in understanding employee engagement. In S.L. Albrecht (Ed.), Handbook of Employee Engagement. Perspectives, Issues, Research and Practice. New Horizon in Management (pp. 159-173). Northampton: Edward Elgar.

Schoorman, F.D., Mayer, R.C., \& Davis, J.H. (2007). An integrative model of organizational trust: past, present, and future. Academy of Management Review, 32(2), 344-354.

Schreiner, M., Kale, P., \& Corsten, D. (2009). What really is alliance management capability and how does it impact alliance outcomes and success?. Strategic Management Journal, 30, 1395-1419.

Scott, C.L. (1980). Interpersonal trust: A comparison of attitudinal and situational factors. Human Relations, 33, 805-812.

Seppänen, R., Blomqvist, K., \& Sundqvist, S. (2007). Measuring inter-organizational trust-a critical review of the empirical research in 1990-2003. Industrial Marketing Management, 36(2), 249-265.

Simpson, M.R. (2009). Engagement at work: A review of the literature. International Journal of Nursing Studies, 46(7), 1012-1024.

Sluyts, K., \& Martens, R. (2009). Enabling Effective Alliance Capability Building. Proceedings of the 25th IMP conference, Marseille, France.

Speakman, R., Isabella, L., \& MacAvoy, T. (2000). Alliance Competence. Maximizing the Value of Your Partnerships. Hoboken: John Wiley \& Sons.

Stevens, S.S. (1946). On the Theory of Scales of Measurement. Science. New Series, 103(2684), 677-680.

Sulimowska-Formowicz, M. (2015). Relational competence of a firm as a determinant of interorganizational relations' effectiveness and efficiency - a study from Polish market. Proceedings of the 31 IMP Conference, Kolding, Denmark.

Wales, W.J., Parida, V., \& Patel, P.C. (2013, April). Too much of a good thing? absorptive capacity, firm performance, and the moderating role of entrepreneurial orientation. Strate- 
gic Management Journal, 34(5), 622-633.

Walter, A. (1999). Relationship Promoters - Driving Forces for Successful Customer Relationships. Industrial Marketing Management, 28(5), 537-551.

Walter, A., Auer, M., \& Ritter, T. (2006). The impact of network capabilities and entrepreneurial orientation on university spin-off performance. Journal of Business Venturing, 21(4), 541-567.

Wu, W.-L., Lin, C.-H., Hsu, B.-F., \& Yeh, R.-S. (2009). Interpersonal trust and knowledge sharing: Moderating effects of individual altruism and a social interaction environment. Social Behavior and Personality: An International Journal, 37(1), 83-93.

Xanthopoulou, D., Bakker, A.B., Demerouti, E., \& Schaufeli, W.B. (2009). Reciprocal relationships between job resources, personal resources, and work engagement. Journal of Vocational Behavior, 74(3), 235-244.

Yeh, W.-L., Wu, C.-H., Lin, B.-F., \& Hsu, R.-S. (2009). Interpersonal trust and knowledge sharing: moderating effects of individual altruism and a social interaction environment. Social Behavior and Personality, 37(1), 83-94.

Young, L., \& Daniel, K. (2003). Affectual trust in the workplace. The International Journal of Human Resource Management, 14(1), 139-155.

Zaheer, A., Lofstrom, S., \& George, V.P. (2003). Interpersonal and Interorganizational Trust in Alliances. In F. J. Contractor \& P. Lorange (Eds.), Cooperative Strategies and Alliances (pp. 347-377). Binglay: Emerald.

Zaheer, A., McEvily, B., \& Perrone, V. (1998). Does Trust Matter? Exploring the Effects of Interorganizational and Interpersonal Trust on Performance. Organization Science, 9(2), 141-159.

Zollo, M., Reuer, J.J., \& Singh, H. (2002). Interorganizational Routines and Performance in Strategic Alliances. Organization Science, 13(6), 701-713.

Zollo, M., \& Winter, S.G. (2002). Deliberate learning and the evolution of dynamic capabilities. Organization Science, 13(3), 339-351. 


\section{Authors}

The contribution share of authors is equal and amounted to $1 / 3$ each of them.

\section{Małgorzata Chrupała-Pniak}

Her research interests focus on work engagement and motivation processes, work team's effectiveness, shared and transformational leadership and human resources management.

Correspondence to: Małgorzata Chrupała-Pniak, PhD, University of Silesia in Katowice, Poland; Institute of Psychology; Work and Organizational Psychology Department; e-mail: malgorzata.chrupala-pniak@us.edu.pl

\section{Damian Grabowski}

His research interests focus on work ethic, work engagement, motivation processes and organizational commitment.

Correspondence to: Damian Grabowski, PhD, University of Silesia in Katowice, Poland; Institute of Psychology; Work and Organizational Psychology Department; SWPS University of Social Sciences and Humanities, Poland; Katowice Faculty of Psychology; e-mail: damian.grabowski@swps.edu.pl

\section{Monika Sulimowska-Formowicz}

Her research interests focus on relational competence of organizations, company competitiveness and strategic management.

Correspondence to: Monika Sulimowska-Formowicz, PhD, University of Economics in Katowice, Faculty of Management, Department of International Management, ul. Bogucicka 14, 40-287 Katowice, Poland; e-mail: mformowicz@ue.katowice.pl

\section{Acknowledgements and Financial Disclosure}

This article is an outcome of the project entitled: 'Relational competence as a determinant of effectiveness and efficiency of inter-organizational relations. The project benefited financial support from the Polish National Centre of Science (Narodowe Centrum Nauki) - Decision no. DEC-2012/05/B/HS4/03635 (project leader - Monika Sulimowska-Formowicz).

\section{Copyright and License}

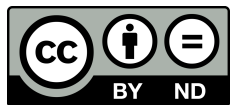

This article is published under the terms of the Creative Commons Attribution - NoDerivs (CC BY- ND 4.0) License http://creativecommons.org/licenses/by-nd/4.0/

\section{Published by the Centre for Strategic and International Entrepreneurship - Krakow, Poland}


